VERSITA
SJAS 2014, 11 (1): 43-52

ISSN 2217-8090

UDK: 005.574:305-055.1/.2

DOI: $10.5937 /$ sjas11-5298

Original paper/Originalni naučni rad

\title{
THE EFFECT OF GENDER ON NEGOTIATION BEHAVIOUR
}

\section{Gordana Dobrijević*}

Singidunum University, Department of Business

32 Danijelova Street, Belgrade, Serbia

\begin{abstract}
:
As men and women have different roles in society, their negotiating styles and behaviours are also different. The success of men and women in negotiations depends largely on the type of negotiation (integrative or distributive) and gender stereotypes prevailing in society. There is a general opinion that women are more cooperative, while men are more aggressive and competitive in negotiations. Our findings from the Serbian setting show a somewhat different picture: women do not use more cooperative strategies and tactics than men. Although men focus on winning, they also focus on problem solving; while women focus on conflict avoidance, and, to a certain extent, on mutual relationship. Women are also more sensitive to their counterpart's age and gender. But, they are also less sincere in negotiations and focus on their own interests, rather than taking care of their own as well as other party's interests. A major theoretical implication of this research is that the observed differences in the behaviour of female negotiators reflect the pressure to be successful in a male-dominated society where gender stereotypes are quite prominent.
\end{abstract}

\section{Key words:}

negotiation,

men,

women,

gender differences,

gender stereotypes.

\section{INTRODUCTION}

Negotiation is one of the ways by which people deal with their differences and many challenges they encounter. There are many situations in life and in business that we try to solve by means of negotiation: friends negotiate to decide where to have lunch, nations negotiate about borders, and companies negotiate about buying or selling their products. People negotiate all the time, although often they are not even aware of it.

Obviously, some people are better negotiators than others, due to individual differences. We all have a natural style that influences our negotiations with others, although we adapt that preferred style to the particular situation and participants. The main factors influencing the negotiation style are personality, culture, and gender (Dobrijević, 2009).
This paper presents an analysis that builds on past research on gender and negotiation. The main purpose of this study was to investigate gender differences among professionals in Serbia. This study tries to contribute to the literature on negotiation in several ways. First, we combine theoretical constructs from the literature on negotiation and gender in general. We examine various gender differences and stereotypes, based on theoretical and empirical work of eminent authors. Second, we try to understand gender differences in the Serbian setting. Understanding gender differences is theoretically and empirically important because it can improve the negotiation outcome, especially for women. This paper also contributes to the literature on international management because of its focus on a particular nation. After decades of war and political and economic crisis, the whole Western Balkans has opened up to new opportunities and integration, and Serbia has 
recently signed the EU Stabilization and Association Agreement.

\section{SOCIAL ROLES OF MEN AND WOMEN}

Although the terms sex and gender are commonly used as synonyms, scientists make a clear distinction: sex refers to the biological categories of male and female, while gender refers to "the cultural and psychological markers of the sexes" - the features of role that distinguish men from women in some culture or society (Lewicki et al., 2010, p. 404).

We can identify different gender roles, which do not necessarily correspond to the existing sexual stereotypes. Holt and Ellis (as cited in Canet-Giner and Saorín-Iborra, 2007, p. 212) defined gender roles as "expectations about what is appropriate behaviour for each sex". Apart from the masculine and feminine profiles, research has shown other gender roles, such as androgyny and undifferentiated profiles (Brewer et al., 2002). While masculine profiles are characterised as competitive, assertive, analytical, dominant, and individualistic, feminine profiles are depicted as sympathetic, affectionate, soft-spoken, understanding, and sensitive to the needs of others. According to Brewer et al. (2002), androgynous profiles show high levels of both masculinity and femininity. They are more flexible and adaptable; they can play different roles, as appropriate in a given situation. Contrarily, undifferentiated individuals have low levels of both kinds of behaviour. However, we are not going to engage in the analysis of this undifferentiated profile, but focus on the differences between "traditionally" male and female gender/sex.

According to Judith Briles (as cited in Wyatt, 1999), it seems that early childhood plays tell a lot about a person's future business style, especially in negotiations. She thinks that the society we live in defines appropriate roles for both genders, as they are culturally conditioned. While men see business as a team sport and play aggressively, women perceive business as a series of personal meetings. They are generally taught to get along with others and be nice. In many cultures, e.g. Serbia, girls' toys include various household appliances, by which they learn to be "good housewives". According to Wyatt (1999), women negotiate for what is fair and men play to win. That is probably one of the main reasons why women achieve better results in cooperative negotiations, and men are better in competitive negotiations.
According to Wirls (as cited in Yeganeh and May, 2011), distinct gender roles lead to considerable inequalities in many social, political, economic, financial, educational, conjugal, and work-related issues. In business environment, women often imitate male behaviour in order to succeed in their career (Vanderbroeck, 2010). Various pieces of research (e.g. Reuvers et al., 2008; Eagly and Johnson, 1990) have shown that women and men (although equally successful as leaders) have different leadership styles - while women are more focused on employee well-being, men focus on domination over others and solving tasks, which corresponds to stereotypical male and female behaviour. A recent study by Vinkenburg et al. (2011) investigated stereotypes about the importance of leadership styles for the promotion of women and men to different levels in organizations. Inspirational motivation (optimism and excitement about the future) was seen as more important for men than women, particularly for a promotion to CEO. On the contrary, individualized consideration (development and mentoring of followers) was seen as more critical for women than men, especially for the advancement to senior management.

In Serbia even the choice of one's profession is many times strongly influenced by inherited stereotypes. Women normally engage in humanities (around 65 per cent), while men study engineering (75 per cent). Both genders are equally represented in medicine (Kolin and Čičkarić, 2010). Almost all of Serbian elementary school teachers are women. In Serbia we even had the opportunity of seeing TV advertisements promoting stereotype-free working environment where "even a young woman could be" an engineer or a manager.

\section{NEGOTIATION BEHAVIOUR}

Negotiation behaviour is tactical. Negotiators try to attain their goals by gaining their counterparts' consent through influence. Various behavioural tactics are used in negotiations regardless of the negotiators' general strategy, e.g. cooperative or competitive (Rao and Schmidt, 1998). These tactics can be verbal and non-verbal. Generally, when we talk about cooperative negotiation behaviour, we think of openness and information sharing, asking open-ended questions, listening, and creating empathy. This kind of communications normally leads to mutual understanding. On the other hand, competitive behaviour includes threats, demands, 
withholding information, poor mouthing, setting deadlines, etc. As such, this kind of behaviour leads to less effective communication.

Canet-Giner and Saorín-Iborra (2007) present the distinction between integrative and competitive behaviours as a continuum and not as a dichotomy. This means that negotiating parties can display different behaviours involving integrative and competitive orientations, resulting in different levels of communicative effectiveness. In addition, negotiators can adopt different types of behaviour throughout the interaction (Lax and Sebenius, as cited in CanetGiner and Saorín-Iborra, 2007).

While there have been many studies emphasizing the differences in cooperative-competitive orientation between men and women, some evidence also shows that these differences are insignificant (Westbrook et al., 2011). In a cross-cultural study, Lynn (as cited in Westbrook et al., 2011) surveyed students from 20 countries and found that men scored higher on competitiveness than women in only six of the 20. These were the USA, Canada, the UK, Germany, Iceland, and Ireland. It seems that men's higher degree of competitiveness is not universal and may be more in line with cultural aspects of their country of origin. The authors believe that over time, and due to changes in organizational socialization and increased teamwork, the gap between men's and women's level of competitiveness gets narrower. Empirical results from their study showed no differences between men and women with a hypercompetitive attitude, supporting earlier theories that the gap in competitiveness between men and women is decreasing.

\section{GENDER AND NEGOTIATION BEHAVIOUR}

During the last several decades there have been many pieces of research on gender in negotiations, e.g. Wall (1976) and Druckman et al. (1977). The studies have shown two significant distinctions between male and female negotiators. Firstly, on average, men behave more competitively than women, and secondly, on average, men have better results than women (Kray, 2007). Some studies of competitive bargaining found that women are likely to be less competitive and have worse outcomes than men (Stuhlmacher and Walters; Walters et al., as cited in Amanatullah, 2008).

There is a general perception that women are more cooperative while men are more aggressive and competitive (Babladelis et al., as cited in Westbrook et al., 2011). According to Calhoun and Smith (1999), women are also more likely to rate themselves as friendly and trustworthy. Results of a study carried out by Brahnam et al. (2005) indicate that women are more inclined to use a collaborative conflict resolution style and men tend to avoid conflict. Since cooperation is generally seen as more useful and avoidance more obstructing in the conflict resolution process, their study suggests that women may have more productive conflict resolution characteristics than men. The research of Brewer et al. (2002) shows that masculine gender role is more likely to be correlated with the dominating conflict style, feminine orientation with the avoiding conflict style, and androgynous orientation with the integrating conflict management style. There was no evidence about the correlation between gender role and the compromising conflict management style.

According to Lewicki et al. (2010), there are five cognitive and behavioural processes that indicate gender differences in negotiation:

1. Men and women think of negotiations in different ways -what the negotiation is all about. While women concentrate on relationships, men concentrate on tasks;

2. Men and women communicate differently while men tend to discuss positions, women disclose more personal information and emotions;

3. Men and women are regarded differently in negotiations - there is evidence that women are often treated worse than men in negotiations;

4. There are different effects of similar tactics when used by men and women - women who use exchange tactics are less successful than men;

5. Gender stereotypes influence negotiator performance - if they are aware of some gender stereotypes, they will act in ways that support those stereotypes.

Gender stereotypes have a major impact on men's and women's success and behaviour in negotiations. Female empathy and better communication skills are the usual gender stereotypes. However, in the research carried out by Kray et al., 2002 (as cited in Kray, 2007, p. 163), reminding negotiators of these feminine features before a mixed-gender negotiation actually led women to outperform their male adversaries. Female negotiators approached negotiations more assertively and with higher expectations of their ability to succeed, which are two critical characteristics that can help any negotiator to reach 
a better outcome. Kray (2007) also says that context is a stronger predictor of negotiation performance than gender. The beliefs the negotiators bring with them to negotiations dictate the goals they set, their behaviour, and performance.

Persisting is stereotypically a masculine response. Riley Bowles and Flynn (2010) studied how gender influences persistence in negotiation. They found that actual persistence behaviour in negotiation is not a simple result of gender stereotype. They claim that the impact of gender on persistence is better predicted by the gender pairing in a dyad than by the gender of an individual negotiator. Their results show that women persist more, but in more indirect ways, with male than with female naysayers. Their results challenge the gender-stereotypic reasoning that men persist more than women, showing that it is the gender composition of a negotiating dyad that matters more than the gender of an individual negotiator.

Very often women fail to initiate negotiations, even if it would be in their best interest. Babcock and Laschever (2010) confirmed that in several pieces of research. Men ask for things they want and start negotiations much more often than women - two to three times as often. They believe this is the explanation of why men in average earn 7-8 per cent more than women. Women either silently accept what they are offered or complain, but they rarely ask for more. These authors emphasize the fact that the most important step in any negotiation is deciding to negotiate in the first place.

A research by Yeganeh and May (2011) brought some new insight on cultural dimensions and the so called gender gap. The global gender gap index (GGI), introduced in 2006 by the World Economic Forum, is a "measure that captures national genderbased inequalities on economic, political, education, and health-based criteria" (Hausmann et al., 2007, as cited in Yeganeh and May, 2011, p. 109). The authors found that socio-economic development, cultural values, and the gender gap are closely intertwined. The results indicate that countries with higher conservative values (like Islamic nations) are more likely to emphasize the gender inequality, unlike the Nordic region on the other extreme.

\section{FACTORS THAT MAKE GENDER RELEVANT IN NEGOTIATIONS}

According to Riley and McGinn (2002), there are some situational factors that make gender relevant to behaviour or expectations. They call them "gender triggers". There are many different potential gender triggers in negotiation. They do not necessarily create identical outcomes (e.g. gender triggers do not always benefit male over female negotiators), but they implicitly or explicitly increase the negotiators' awareness of gender as a social factor. Gender-based social roles are one form of the gender trigger. Gender roles can influence negotiators by putting restrictions on what is regarded as attractive or appropriate negotiating behaviour (Eagly, 1987, as cited in Riley and McGinn, 2002).

Karakowsky and Miller (2006) claim that the role of gender in mixed gender, multi-party negotiations can appear through three critical elements: the proportional representation of the two sexes in the negotiation, their gender roles, and their perceived status. According to Rosabeth Kanter's theory of proportional representation (as cited in Karakowsky and Miller, 2006) it is the numerical representation of men or women in a group rather than gender roles that dictates the behaviour of men or women. Individuals are in a minority position if they (e.g. women) account for less than 15 per cent of the organisation's members. According to Kanter, individuals in this numerical minority position are usually seen as representatives of their social categories rather than as individuals. Stereotypes about what is appropriate behaviour for men and women maintain that men are more task-oriented, and focused on distributive and aggressive strategies, while women prefer win/ win negotiations, and have higher lever of socioemotional behaviour. Also, gender differences in behaviour will be affected by perceptions of the status or expertise that group members have. In a mixedgender, multi-party negotiation, individuals (males or females) who are in a numerical minority position, will exercise less influence compared to individuals who are in a numerical majority position. Therefore, negotiators in the minority will be less likely to use competitive tactics. In this research, Karakowsky and Miller reached two important conclusions about mixed-gender multi-party negotiations:

1. Men will exercise greater influence compared to women when the negotiation clearly contains the potential for a distributive outcome, which is a stereotypical male-oriented negotiation task;

2. Women will have greater influence compared to men when the negotiation clearly shows the potential for an integrative outcome (a stereotypical female-oriented task). 
Schroth et al. (2005) explored how gender can influence the intensity to which particular words prompt emotional responses in negotiations. They found out that, although some words and phrases induce emotional responses when used in negotiations, they do not always influence the perception of negotiations in the same way. Words that tell the other person what to do, or are rude normally evoke frustration or anger and lead to the user being perceived as unfair. However, when those words are used, observers, especially women, seem more optimistic that the negotiation will be successfully resolved. Regardless of the fact that women tend to be more relationship oriented in negotiations than men, the language that would seem to hurt a relationship was not seen as negative by women. Although rude comments and being told what to do made both men and women feel anger and frustration, women were more influenced by being told what to do (especially by another woman) than men, but men were more affected by rude comments (especially by other men) than women.

Hanappi-Egger and Kauer (2010) analysed the contextual factors which lead to gender switching in bargaining situations. They see bargaining as a gendered process, not biologically determined. Their results showed that bargaining is a masculine construction. "The bargaining parties mainly have masculinely connoted scripts ... in their minds when it comes to bargain" (pp. 505-506). For these authors, maleness or masculinity seems to be the key for successful bargaining.

According to Amanatullah (2008), advocacy lessens gender differences in negotiations. In her empirical study self-advocating female negotiators agreed to lower salaries than men and other-advocating women, and they also used less competing conflict resolution styles than men, while in conditions of other-advocacy women and men used competing styles equally. According to this author, women's timid behaviour is a rational reaction to avoid social costs that are provoked by women in self-advocating negotiations, which does not mean that women are unable or unmotivated to negotiate effectively. When these costs are removed, i.e. when negotiators represent somebody else, women behave and perform similarly to men.

\section{RESEARCH}

Based on our literature review, we investigated five specific hypotheses:
Dobrijević G. $\diamond$ The effect of gender on negotiation behaviour

H1. Men focus on winning more than women.

H2. Women focus more on relationship with the other side than men.

H3a. Women negotiators use more cooperative strategies and tactics than men.

H3b. Women negotiators are more open and sincere in disclosing information

H4. Women negotiators are more sensitive to the age and gender of the opposing party.

\section{Methodology}

After reviewing the contemporary literature, the theoretical model was constructed and the differences were hypothesized. Data were collected via a questionnaire distributed by e-mail to 200 individuals. The questionnaire had fifteen closed-ended questions about various aspects of negotiations: negotiation strategy and planning, goal setting, concession making, influence of age and gender on negotiators, negotiation tactics, and mediation. Likert scale was used to scale responses in the majority of the questions. The data were subsequently analysed using quantitative procedures.

\section{Participants}

We chose a sampling strategy that would capture perceptions from different groups of managers and employees. No sampling frame was available. We used purposive sampling, trying to have participants from private and public sector, from national and international organizations, from Belgrade and the rest of Serbia, both men and women. There were 200 working adults, 104 men and 96 women, from various industries.

\section{Limitations}

The scope and geographical spread are limiting factors of this research which, to a large extent, influenced the limitations of the results obtained. It cannot be used to make generalizations about the entire population, since it is based on a small and unrepresentative number of cases. However, it does help us understand gender differences in negotiations.

\section{Results}

In order to confirm these hypotheses, we crossreferenced the answers to several questions with the respondents' gender. 


\section{H1. Men focus on winning more than women.}

Only 1 per cent more men than women consider winning the most important thing in negotiations (figure 1). However, if we consider those who rated winning 1 and 2 (almost 32 per cent men, 27 per cent women), and those who give least importance to winning (4 and 5 - 40 per cent men, almost 49 per cent women), we can see that the overall results show that men value winning more than women.

\section{H2. Women focus more on relationship with the other side than men.}

This hypothesis is partially confirmed. There is just a little difference between respondents who focus on mutual relationship: 12.5 per cent men and 14.58 women rated relationship 1, 16.35 per cent men and 18.75 women rated relationship 2. Also, to the question "Do you care only about your own interests, or also about the interests of others?" more women (12.5 per cent) than men (8.65 per cent) said they care only about their own interests (figure 2)

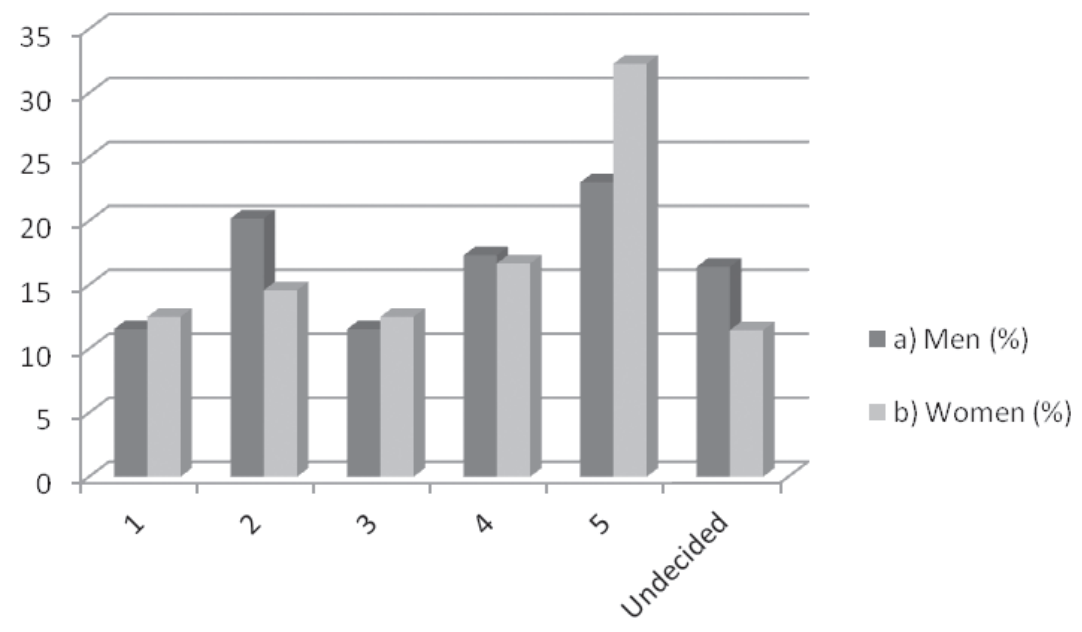

Figure 1. Focus on winning

1 - very important, 2 -important, 3-moderately important, 4-of little importance, 5-unimportant

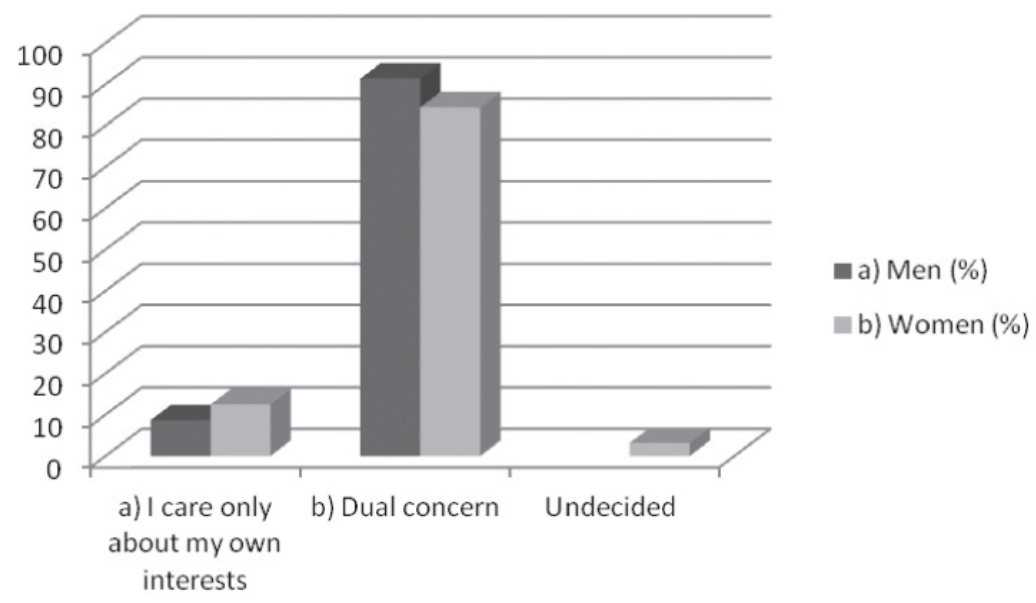

Figure 2. Own and others' interests 
H3a. Women negotiators use more cooperative strategies and tactics than men.

Men focus on winning more than women, but on the other hand, men also focus more on problem solving than women (see figure 3 ). Both genders equally rated conflict avoidance, but if we consider respondents who rated conflict avoidance 1 and 2, we get 31.25 per cent women and 13.46 per cent men. Also, 24.04 per cent men rated this feature as the least important, versus 15.62 per cent women (figure 4).

As we stated earlier, more women (12 per cent) care only about their own interest than men (8 per cent).
At the same time, the difference in women and men focusing on mutual relationship is not very significant. The hypothesis that women negotiators use more cooperative strategies and tactics than men was not confirmed. The results have only shown that men are more assertive in negotiations than women because, while women focus more on conflict avoidance and partly on mutual relationship, men are more interested in winning, clearly a competitive strategy (but also on problem solving, which is a cooperative strategy).

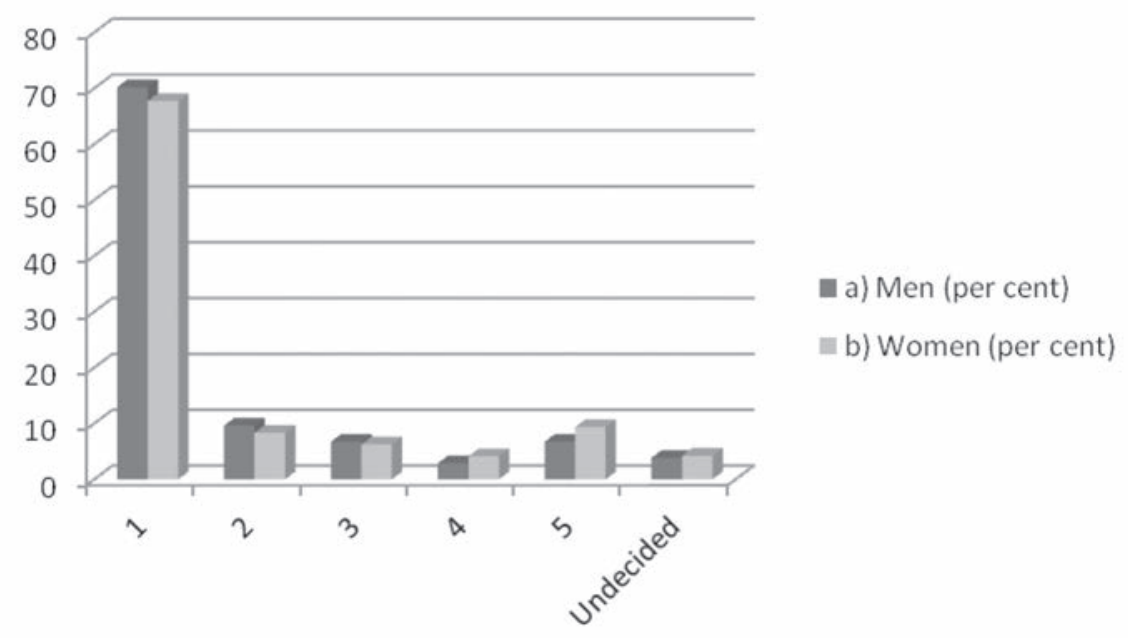

Figure 3. Focus on problem solving

1 - very important, 2 -important, 3-moderately important, 4-of little importance, 5-unimportant

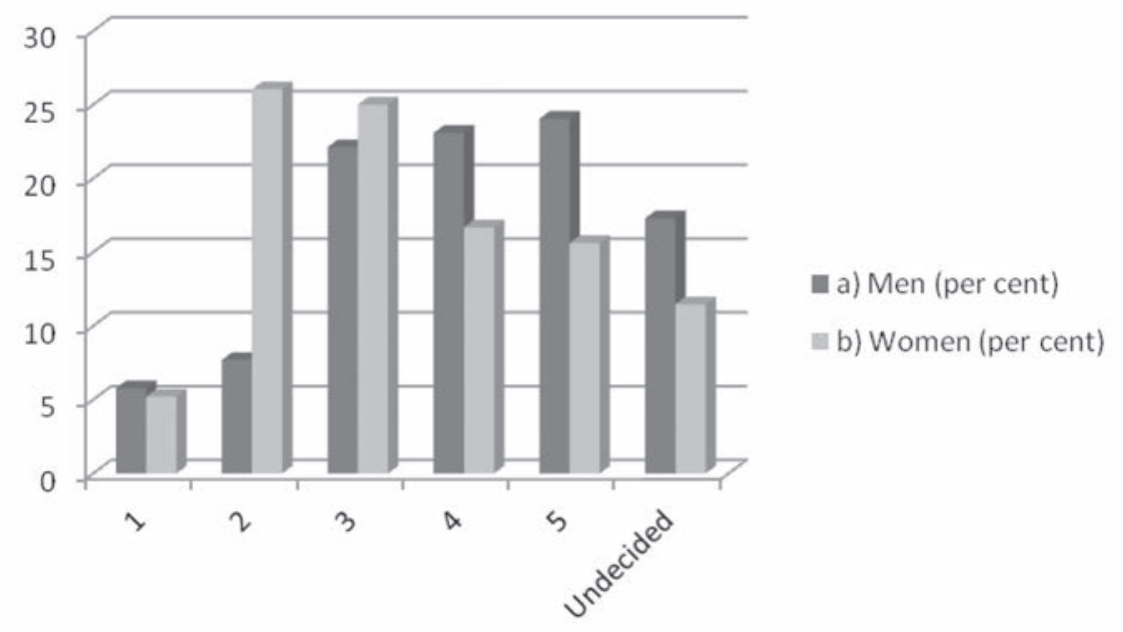

Figure 4. Focus on conflict avoidance

1 - very important, 2 -important, 3 - moderately important, 4-of little importance, 5-unimportant 
H3b. Women negotiators are more open and sincere in disclosing information.

Literature review has shown that women focus more on personal relationships with the opposing side. That led us to propose that women will be more open and truthful in disclosing information.

This hypothesis was disconfirmed. The cross-analysis of gender and sincerity (figure 5) shows that men (33.65 per cent) speak the truth more often than women (26.04 per cent). Although, if we add those who are often honest, we get almost 90 per cent of all the respondents, which is quite promising, talking about the society in general.

\section{H4. Women are more sensitive to the age and gen- der of their opponent.}

The analysis of the results revealed another interesting difference in negotiation: women are more sensitive to the age ( 52.08 per cent women $v s .44 .23$ per cent men) and gender (31.24 per cent women $v s .22 .11$ per cent men) of the other party. That is in accord with the results obtained in a study by Riley Bowles and Flynn (2010). They found that, rather than simply conforming more than men, women adapt their behaviour to the gender of their negotiating counterparts. They become more persistent with male naysayers than with female ones, but doing so they use a different influence style (more low-status) with the male naysayers than with the female naysayers.

\section{CONCLUSIONS}

The main purpose of the study was to investigate gender differences in negotiation in general and to focus on Serbia in the empirical part of the study.

Although in the literature there are contradictory opinions on the impact of gender on negotiation styles and strategies, experience has shown that men and women behave differently in negotiations. Men and women think of negotiations in different ways, they communicate differently during negotiations, and similar tactics have different effects in negotiations, depending on the gender that uses them. Probably the initial difference in pay between men and women in many cases comes as a result of the reluctance of women to start negotiations with the employer. Experience has shown that women are generally better in integrative negotiations, while men are more successful in distributive, although there are some pieces of research that disconfirm that opinion.

Our empirical research has not confirmed the opinion that women use cooperative tactics more than men. We have reached the conclusion that male negotiators in Serbia are just more assertive than female negotiators. Men focus more on solving problems and winning, and women on conflict avoidance. Contrary to our expectations, more women than men care only about their own interests. Also, men are more sincere in negotiations than women.

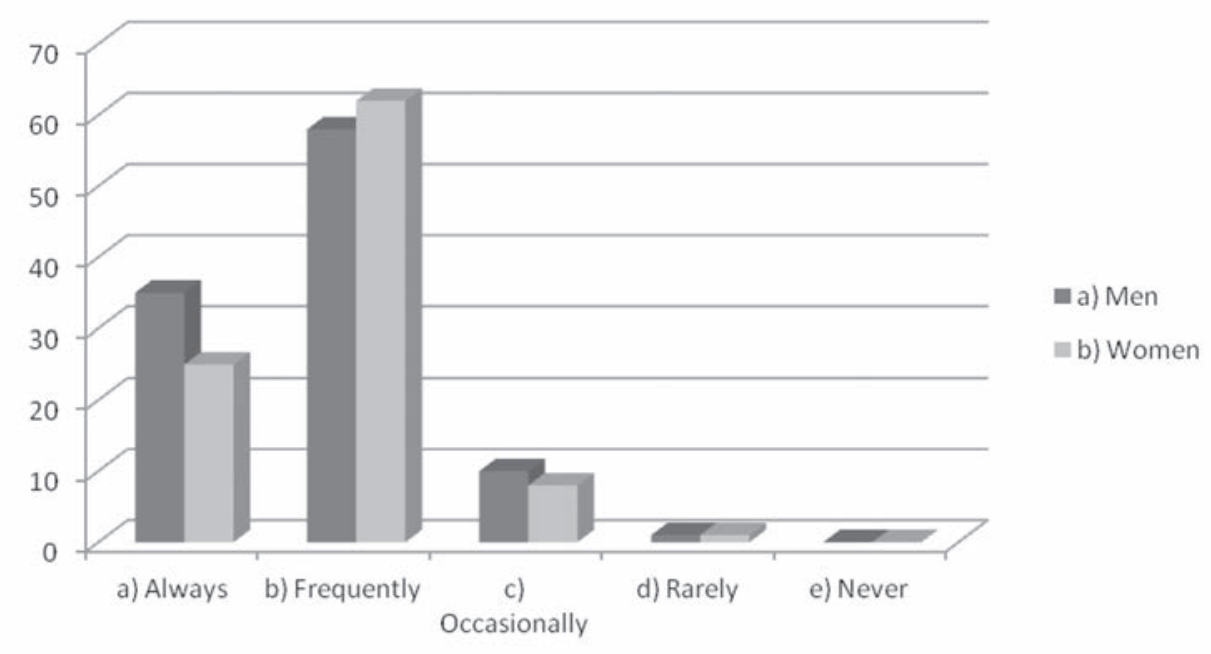

Figure 5. Sincerity 
One explanation that logically presents itself is that, as Serbia is a male-dominated culture, women who want to succeed in the business environment have to be very assertive, and sometimes even ruthless. The analysis of the official EU and UN statistics in the research of Kolin and Čičkarić (2010) shows that women in Serbia are underrepresented in leading positions in governing and decision making in public policy. There are three times fewer women among the legislators, state agencies officials, CEOs, directors, and managers.

Our study confirmed that men focus on winning more than women. We also partially confirmed the hypothesis that women focus on relationship more than men. The hypothesis that female negotiators in Serbia are more sensitive to the age and gender of the other party was fully confirmed.

Our understanding of gender differences is particularly important in situations where the participants of negotiations are members of both genders, because in such situations the differences between men and women will be most visible. Rather than pretend that differences do not exist, we should understand them better. Of course, gender differences are only one element of individual differences between the negotiators. In some international negotiations, they will be even more prominent in case of societies where gender roles differ greatly.

\section{RECOMMENDATIONS FOR FUTURE RESEARCH}

The results of this study offer interesting opportunities for future research. While this particular study utilized a group of two hundred professionals limited to Serbia, it could be replicated on a sample that would represent the wider region of the Balkans. It would also be interesting to engage in a multiple case comparison of Serbian business negotiators with other cultures, according to Hofstede's cultural dimensions (Hofstede, 1983; Geert Hofstede website, 2013) and Inglehart's cultural clusters (Inglehart, 2000). The results could be used in negotiation planning with national and foreign partners, in order to enhance the negotiation outcomes. That would be interesting for negotiators from the Balkans, who, despite their recent differences, are bound to come into closer contact. It would also be of interest to negotiators who come from different cultures, since Serbia, as other countries from the region, is getting more open to the foreign investment.

\section{REFERENCES}

Amanatullah, E.T. (2008). Negotiating gender stereotypes: Other-advocacy reduces social constraints on women in negotiations. Academy Of Management Annual Meeting Proceedings, 1-6. doi: 10.5465/AMBPP.2008.33650222.

Babcock, L., \& Laschever, S. (2010). Women don't ask: Negotiation and the gender divide. In R. Lewicki, D.M. Saunder, \& B. Barry (Ed.), Negotiation: Readings, exercises and cases (pp. 301-308). Singapore: McGraw-Hill International.

Bowles, R.H., \& Flynn, F. (2010). Gender and persistence in negotiation: a dyadic perspective. Academy of Management Journal, 53(4), 769-787. doi: 10.5465/AMJ.2010.52814595.

Brahnam, S.D., Margavio, T.M., Hignite, M.A., Barrier, T.B., \& Chin, J.M. (2005). A gender-based categorization for conflict resolution. Journal of Management Development, 24(3), 197-208. doi: 10.1108/02621710510584026.

Brewer, N., Mitchell, P., \& Weber, N. (2002). Gender role, organizational status, and conflict management styles. International Journal of Conflict Management, 13(1), 78-94. doi: 10.1108/eb022868.

Calhoun, P., \& Smith, W.P. (1999). Integrative bargaining: Does gender make a difference? International Journal of Conflict Management, 10(3), 203-224. doi: 10.1108/ eb022824.

Canet-Giner, T.M., \& Saorín-Iborra, C.M. (2007). The influence of gender role on negotiation development and outcome: A proposal for strategic alliance negotiations. Equal Opportunities International, 26(3), 209-231. doi: 10.1108/02610150710735499.

Dobrijević, G. (2009). Faktori koji oblikuju pregovarački stil u poslovanju. Singidunum revija, 9(1), 183-195. (in Serbian).

Druckman, D., Rozelle, R., \& Zechmeister, K. (1977). Conflict of interest and value dissensus: Two perspectives. In D. Druckman (Ed.), Negotiations: Social psychological perspectives (pp. 105-131). Beverly Hills, CA: Sage.

Eagly, A.H., \& Johnson, B.T. (1990). Gender and leadership style: A meta-analysis. Psychological Bulletin, 108(2), 233-256. doi: 10.1037/0033-2909.108.2.233.

Geert Hofstede website. (2013). Dimensions. Retrieved December 22, 2013, from http://geert-hofstede.com/ dimensions.html.

Hanappi-Egger, E., \& Kauer, A. (2010). Gendered scripts: Studying hidden assumptions in business contexts. Gender in Management: An International Journal, 25(6), 497-508. doi: 10.1108/17542411011069891.

Hofstede, G. (1983). National cultures in four dimensions: A research-based theory of cultural differences among nations. International Studies of Management \& Organization, 13(1-2), 46-74. 
SJAS $2014 \diamond 11(1) \diamond 43-52$

Dobrijević G. $\diamond$ The effect of gender on negotiation behaviour

Inglehart, R. (2000). Culture and Democracy. In S.P. Huntington \& L.E. Harrison (Ed.), Culture matters: How values shape human progress (pp. 80-97). New York: Basic Books.

Karakowsky, L., \& Miller, D.L. (2006). Negotiator style and influence in multi-party negotiations: Exploring the role of gender. Leadership \& Organization Development Journal, 27(1), 50-65. doi: 10.1108/01437730610641368.

Kolin, M., \& Čičkarić, L. (2010). Rodne nejednakosti u zapošljavanju, upravljanju i odlučivanju. Stanovništvo, 48(1), 103-124. (in Serbian). doi: 10.2298/STNV1001103K.

Kray, L.J. (2007). Leading through negotiation: Harnessing the power of gender stereotypes. California Management Review, 50(1), 159-173. doi: 10.2307/41166421.

Lewicki, R.J., Saunders, D.M., \& Barry, B. (2010). Negotiation - readings, exercises and cases. Singapore: McGrawHill.

Rao, A., \& Schmidt, S.M. (1998). A behavioral perspective on negotiating international alliance. Journal of International Business Studies, 29(4), 665-694. doi: 10.1057/ palgrave.jibs.8490047.

Reuvers, M., van Engen, M.L., Vinkenburg, C.J., \& Wilson-Evered, E. (2008). Transformational leadership and innovative work behaviour: Exploring the relevance of gender differences. Creativity and Innovation Management, 17(3), 227-244. doi: 10.1111/j.14678691.2008.00487.x.

Riley, H., \& McGinn, K.L. (2002). When does gender matter in negotiation? Cambridge, Mass: John F. Kennedy School of Government, Harvard University. Retrieved October 15, 2013, from http://research.hks.harvard.edu/ publications/getFile.aspx?Id=51.
Schroth, H.A., Bain-Chekal, J., \& Caldwell, D.F. (2005). Sticks and stones may break bones and words can hurt me: Words and phrases that trigger emotions in negotiations and their effects. International Journal of Conflict Management, 16(2), 102-127. doi: 10.1108/ eb022925.

Vanderbroeck, P. (2010). The traps that keep women from reaching the top and how to avoid them. Journal of Management Development, 29(9), 764-770. doi: 10.1108/02621711011072478.

Vinkenburg, C.J., van Engen, M.L., Eagly, A.H., \& Johannesen-Schmidt, M.C. (2011). An exploration of stereotypical beliefs about leadership styles: Is transformational leadership a route to women's promotion? Leadership Quarterly, 22(1), 10-21. doi: 10.1016/j. leaqua.2010.12.003.

Wall, J.A. (1976). Effects of sex and opposing representative's bargaining orientation on intergroup bargaining. Journal of Personality and Social Psychology, 33(1), 5561. doi: 10.1037/0022-3514.33.1.55.

Westbrook, K.W., Arendall, C.S., \& Padelford, W.M. (2011). Gender, competitiveness, and unethical negotiation strategies. Gender in Management: An International Journal, 26(4), 289-310. doi: 10.1108/17542411111144300.

Wyatt, D. (1999). Negotiation strategies for men and women. Nursing management, 30(1), 22-26.

Yeganeh, H., \& May, D. (2011). Cultural values and gender gap: A cross-national analysis. Gender in Management: An International Journal, 26(2), 106-121. doi: $10.1108 / 17542411111116536$.

\section{UTICAJ RODA NA PONAŠANJE U PREGOVORIMA}

\section{Rezime:}

Pošto muškarci i žene imaju različite uloge u društvu, njihovi pregovarački stilovi i ponašanja se takođe razlikuju. Pregovarački uspeh muškaraca i žena u velikoj meri zavisi od vrste pregovora (saradnički ili suparnički) i rodnih stereotipa koji su izraženi u datom društvu. Uobičajeno je mišljenje da žene više sarađuju, dok se muškarci više nadmeću i agresivniji su. Naše istraživanje u Srbiji pokazalo je malo drugačiju sliku: žene ne koriste više saradničke strategije i taktike nego muškarci. Iako se muškarci fokusiraju na pobedu, takođe se fokusiraju na rešavanje problema, dok se žene fokusiraju na izbegavanje konflikta i, u manjoj meri, na međusobne odnose. Žene su takođe osetljivije na godine i rod pregovarača druge strane. Ali, one su takođe manje iskrene u pregovaranju i fokusiraju se na vlastite interese, umesto da uzimaju u obzir i interese druge strane. Glavna teorijska implikacija ovog istraživanja je da opažene razlike u ponašanju kod pregovarača ženskog roda odslikavaju pritisak da uspeju u društvu u kojem dominiraju muškarci i u kojem su rodni stereotipi dosta izraženi.

\author{
Ključne reči: \\ pregovaranje, \\ muškarci, \\ žene, \\ rodne razlike, \\ rodni stereotipi.
}

Received: January 8th, 2014. Correction: January 28th, 2014. Accepted: February 1st, 2014. 